\title{
T CELL RECEPTOR V $\beta$ GENE EXPRESSION IN EXPERIMENTAL HERPES STROMAL KERATITIS
}

\author{
MIGUEL PEDROZA-SERES ${ }^{1,2}$, STEPHANIE GOEI ${ }^{2}$, JESUS MERAYO-LLOVES ${ }^{1}$, \\ JAMES E. DUTT ${ }^{1}$, SOON J. LEE ${ }^{1}$, VICTOR ARRUNATEGUI-CORREA ${ }^{1}$ and \\ C. STEPHEN FOSTER ${ }^{1}$ \\ Boston, Massachusetts and Mexico City
}

\begin{abstract}
SUMMARY
Our study examined $T$ cell receptor (TCR) V $\beta$ mRNA expression in a murine model of experimental herpes simplex keratitis (HSK). We employed a polymerase chain reaction (PCR) technique to detect TCR V $\beta$ mRNA expression in the inoculated eyes of both HSKsusceptible and HSK-resistant mice at different time points after corneal inoculation with herpes simplex virus type 1 (HSV-1), followed by Southern blotting and densitometry analysis. In eyes from HSK-susceptible C.AL-20 mice, a more diverse TCR V $\beta$ transcript usage pattern was detected as compared with that seen in HSK-resistant C.B-17 mice. $V \beta 8$ family members were expressed in both strains of mice at days 11, 14 and 21 post-inoculation. By densitometry, at day 11, the intensity of expression of $V \beta 8.2$ and $V \beta 8.3$ message was significantly greater in the eyes of C.AL-20 mice; Vß8.1 was expressed only in C.B-17 mice. There were obvious differences in the TCR V $\beta$ expression between HSKsusceptible and HSK-resistant mice. The differences in the intensity of the message expressed by $V \beta 8$ family members between the two strains could be correlated to previous experiments that showed $V \beta 8.1,2+T$ cells as the main infiltrating cells in the corneas of HSKsusceptible mice by day 11 and 14 after challenge with HSV-1.
\end{abstract}

Herpetic stromal keratitis (HSK) in mice is a representative model of the blinding corneal disease induced by herpes simplex virus type 1 (HSV-1) in humans. During the past several years, $\mathrm{we}^{1}$ and others $^{2-5}$ have consistently found that immune mechanisms involving $\mathrm{T}$ cells play a major role in the pathogenesis of HSK. We have discovered a major

From: ${ }^{1}$ Hilles Immunology and Rhoads Molecular Immunology Laboratories, Massachusetts Eye and Ear Infirmary, Harvard Medical School, Boston, Massachusetts, USA; ${ }^{2}$ Facultad de Medicina, Universidad Nacional Autonoma de México, Mexico City.

Correspondence to: C. Stephen Foster, Massachusetts Eye and Ear Infirmary, 243 Charles Street, Boston, MA 02114, USA. influence of the Igh-1 gene locus on the clinical expression of HSV infection by using Igh-1 disparate BALB/c congenic strains of mice; ${ }^{6}$ C.AL-20 (H-2 ${ }^{\mathrm{d}}$, Igh- ${ }^{\mathrm{d}}$ ) mice develop severe keratopathy, whereas C.B-17 $\left(\mathrm{H}-2^{\mathrm{d}}, \mathrm{Igh}-\mathrm{1}^{\mathrm{b}}\right)$ mice are extremely resistant to HSK. The results of experiments performed in several laboratories, including our own, have led to the notion that $\mathrm{CD} 4+\mathrm{T}$ cells are involved in the induction of $\mathrm{HSK}$, at least in BALB/c mice, and that CD8+ T cells may play a role in protection from HSK. ${ }^{7,8}$

Studies directed towards the elucidation of whether or not there is a preferential $\mathrm{T}$ cell receptor (TCR) V $\beta$ usage in the keratitis model showed a restricted repertoire of $T$ cells infiltrating the corneas of susceptible mice; immunohistochemical studies showed that $\mathrm{V} \beta 8.1,2+\mathrm{T}$ cells were the main infiltrating cells by day 11 and 14 after challenge with HSV-1, with fewer numbers of $\mathrm{V} \beta 3+$ and $\mathrm{V} \beta 6+$ cells seen. ${ }^{9}$ Adoptive transfer of a herpes glycoprotein-D peptide specific, CD4+ V $38.2+$, interleukin 4 (IL-4) producing Th2 clone prior to corneal challenge with HSV-1 accelerated the onset and increased the severity of HSK in susceptible mice, and rendered resistant mice susceptible to HSK. ${ }^{10}$ Finally, the in vivo depletion of $\mathrm{V} \beta 8+$ or $\mathrm{V} \beta 3+\mathrm{T}$ cells using monoclonal antibodies reduced the incidence and severity of HSK in susceptible C.AL20 mice compared with untreated mice. ${ }^{1}$

In the present study, we have analysed the TCR $\mathrm{V} \beta$ repertoire in the eyes of C.AL-20 and C.B-17 mice before and after corneal inoculation with HSV1 in an effort to determine whether HSK-susceptible mice preferentially use a restricted TCR V $\beta$ repertoire in response to corneal inoculation with HSV and, if so, whether it is a repertoire different from that used by HSK-resistant mice. The TCR V $\beta$ mRNA expression was analysed by polymerase chain reaction (PCR), followed by Southern blotting and densitometry; such an approach offers 
Table I. Oligonucleotide sequence primers

\begin{tabular}{llc}
\hline V $\beta$ & Sequence & $\begin{array}{c}\text { PCR product } \\
\text { (bp) }\end{array}$ \\
\hline V $\beta 1$ & TGATTCGAAATGAGACGGTG & 458 \\
V $\beta 2$ & GTGCTGATTACCTGGCCACA & 440 \\
V 33 & GAGTGGAGTCAGAAGTCGAT & 450 \\
V $\beta 4$ & CGCTTCCAACCTCAAAGTTC & 442 \\
V 35.1 & GAGAGATAAAGGAAACCTGC & 310 \\
V $\beta 5.2$ & AGCAATGTGGTCTGGTACCAGA & 580 \\
V $\beta 6$ & ATGATGCGTCTCGAGAGAAG & 436 \\
V $\beta 7$ & AGATGGTGGGGGTTTCAAGG & 448 \\
V $\beta 8.1$ & GTCCAAGAAGCAAGGTGGCA & 613 \\
V $\beta 8.2$ & TGCTGGCAGCACTGAGAAA & 428 \\
V $\beta 8.3$ & TAGAAACAAGGTGACAGTAACA & 614 \\
V $\beta 9$ & TTCCAATCCAGTCGGCCTAA & 436 \\
V $\beta 10$ & TCTCACCTCAGTCTTCAGAT & 439 \\
V $\beta 11$ & AACGATTCTCAGCTCAGATG & 434 \\
V $\beta 12$ & CGATTCAAAGCTGAGATGCT & 432 \\
V $\beta 13$ & TCTGCTGTGAGGCCTAAAGG & 436 \\
V $\beta 14$ & CTGAACCTCTCAGCTTCCAG & 439 \\
V $\beta 15$ & CCATCAGTCATCCCAACTTA & 432 \\
V $\beta 16$ & CAGTTGAAAGACCAGATGGT & 427 \\
V $\beta 17$ & GATTCTCAGCTAAGTGTTCC & 432 \\
V $\beta 18$ & CAATCAGCCGGCCAAACCTA & 436 \\
V $\beta 19$ & TGTACTTCTGTGCTAGCAGTC & 290 \\
C $\beta$ & TGCACTTGGCAGCGGAAGTG & 195 \\
\hline
\end{tabular}

bp, base pairs.

significantly greater sensitivity than the immunohistochemistry techniques used in our earlier studies, although it is important to bear in mind that PCR is detecting mRNA expression rather than protein production. An alternative approach using flow cytometry to analyse $\mathrm{V} \beta$ production was not possible due to the severely limited number of $T$ cells recoverable from infected murine corneas.

\section{METHODS}

Mice

Adult 6- to 8-week-old sex-matched C.B-17 (H-2 , Igh-1 $\left.{ }^{\mathrm{b}}\right)$ and C.AL-20 (H-2 ${ }^{\mathrm{d}}$, Igh- $\left.1^{\mathrm{d}}\right)$ mice were purchased from the Jackson Laboratories (Bar Harbor, ME). All the mice were handled according to the Animal Care Guidelines from the National Institute of Health and the ARVO resolution on the use of animals in research.

\section{Virus}

The HSV-1 (KOS strain) stock was donated by Dr Priscilla Schaeffer (Harvard Medical School, Boston, MA) and was grown in our laboratory as previously described. ${ }^{11}$ The same virus passage was used in all experiments.

\section{Corneal Challenge}

Mice were anaesthetised with $2 \mathrm{mg}$ intraperitoneal ketamine $\mathrm{HCl}$ (Ketalar, Parke-Davis, Morris Plains, $\mathrm{NJ}$ ) and xylazine $400 \mu \mathrm{g}$ (Rompun, Mobay, Shawnee, KA). The right cornea of each mouse was scratched eight times in a criss-cross pattern with a 22 gauge needle, and $5 \mu \mathrm{l}$ of an HSV-1 suspension containing $2.5 \times 10^{5} \mathrm{pfu}$ of virus were instilled in the cul-de-sac, as previously described. ${ }^{12}$

\section{Clinical Scoring}

The corneas were examined under binocular microscopy for 21 days after inoculation in order to determine the severity of keratitis. Clinical findings were scored in a masked fashion for the development of stromal oedema and cellular infiltration, corneal neovascularisation, and corneal ulceration, with each parameter graded on a scale of 0 to $4+$, as previously described. ${ }^{11,12}$

\section{PCR Primers and Amplification}

Sequence-specific sense primers for $19 \mathrm{~V} \beta$ families and a primer antisense for the constant region of TCR $\beta$ chain $(C \beta)$ were synthesised using the phosphoramidite method in an automated DNA synthesiser (Pharmacia LKB, Piscataway, NJ) and purified by using Sephadex NAP-10 columns (Pharmacia). The oligonucleotide primer sequences and the expected sizes of the amplified PCR products are listed in Table I.

\section{RNA Isolation and cDNA Synthesis}

Inoculated eyes were harvested from C.B-17 and C.AL-20 mice, both before and at various time points after corneal HSV infection (4, 7, 11, 14 and 21 days post-inoculation). Groups of three mice were used for each time point. Total RNA was extracted using a guanidine thiocyanate/phenol procedure. ${ }^{13}$ Briefly, tissues were homogenised in RNAzol (Cinna Biotecx Laboratory, Houston, TX) using a Polytron homogeniser (Brinkman Instruments, Westbury, NY). RNA was extracted with chloroform, precipitated with isopropanol, washed with $75 \%$ ethanol, and resuspended in DEPC-treated water. The amount of RNA was determined by spectrophotometry. Total RNA was denatured for 10 minutes at $70{ }^{\circ} \mathrm{C}$ and incubated at $37^{\circ} \mathrm{C}$ for 60 minutes with $0.5 \mathrm{mM}$ oligo dT (20-mer), $5 \mathrm{mM}$ dNTPs (Pharmacia), 20 units of RNAsin (Promega, Madison, WI), 20 units of avian myeloblastosis virus (AMV) reverse transcriptase (Boehringer Mannheim, Indianapolis, IN) and 50 $\mathrm{mM}$ Tris- $\mathrm{HCl} \mathrm{pH} 8.3$ in a total volume of $20 \mu \mathrm{l}$. The reverse transcribed cDNA was diluted $1 / 10$ and stored at $-70{ }^{\circ} \mathrm{C}$ until use. Specific primers for $\beta$ actin, a housekeeping gene expressed at a relatively constant level in all cells, were used to verify the integrity of the synthesised cDNA. In addition, preliminary experiments using the $\beta$-actin primers and varying amounts of template cDNA allowed for the selection of an amount of input cDNA for each experimental sample such that subsequent V $\beta$ PCR amplification remained in the linear or exponential phase for all samples studied.

\section{PCR Amplification}

Following the reverse transcription of total RNA into cDNA, PCR was performed by using a wax pellet 
Table II. TCR V $\beta$ transcripts in eyes of C.AL-20 mice (Igh- $\left.1^{\mathrm{d}}\right)$ and C.B-17 mice (Igh- ${ }^{\mathrm{b}}$ )

\begin{tabular}{|c|c|c|c|c|c|c|c|c|c|c|c|c|c|c|c|c|c|c|c|c|c|c|}
\hline \multirow[b]{2}{*}{ Day } & \multicolumn{22}{|c|}{$\mathrm{V} \beta$} \\
\hline & 1 & 2 & 3 & 4 & 5.1 & 5.2 & 6 & 7 & 8.1 & 8.2 & 8.3 & 9 & 10 & 11 & 12 & 13 & 14 & 15 & 16 & 17 & 18 & 19 \\
\hline \multicolumn{23}{|c|}{ C.AL-20 mice } \\
\hline 0 & & & & & & & & & & + & & & & & & & & + & & & & \\
\hline 4 & & & + & & & + & + & & + & + & & & & & & & + & + & & & & \\
\hline 7 & + & + & + & & & & + & & & + & + & + & + & & & & + & + & + & & & \\
\hline 11 & + & + & & + & + & & + & + & & + & + & + & + & + & + & + & + & + & + & & & + \\
\hline 14 & + & + & & + & & & + & + & + & + & + & + & + & & & + & + & + & + & & & + \\
\hline 21 & + & + & & + & + & & + & + & + & + & + & + & + & + & + & + & + & + & & & & + \\
\hline \multicolumn{23}{|c|}{ C. $B-17$ mice } \\
\hline 0 & & & + & & & & & & & + & + & & & & & & + & + & & & & + \\
\hline 4 & + & & + & & & & & & + & + & + & & & & & & + & & & & & \\
\hline 7 & + & + & & + & & & + & & + & + & + & & & & & & + & + & + & & & + \\
\hline 11 & + & & & & & & & & + & + & + & & & & & & + & & & & & \\
\hline 14 & & & & & & & & & + & + & + & & & + & & & & + & & & & + \\
\hline 21 & & & & & & + & + & + & & + & + & & + & & & + & & + & & & & + \\
\hline
\end{tabular}

Expression of V $\beta$ TCR in congenic mice at several time points detected by PCR. ' + ' indicate presence of V $\beta 1$, while blank means absence.

hot-start technique. Briefly, the lower reagent mix of the reverse transcriptase polymerase chain reaction (RT-PCR) contained a final concentration of 12.5 $\mathrm{mM}$ Tris- $\mathrm{HCl} \mathrm{pH} 8.3,62.5 \mathrm{mM} \mathrm{KCl}$ (Perkin Elmer, Norwalk, CT), $2.5 \mathrm{mM} \mathrm{MgCl}_{2}, 200 \mu \mathrm{M}$ of each dNTP (Pharmacia), and $20 \mathrm{pmol}$ of each primer. An AmpliWax PCR Gem 100 (Perkin Elmer) was added to each tube. All the tubes were incubated at $80{ }^{\circ} \mathrm{C}$ for 5 minutes and cooled to $4{ }^{\circ} \mathrm{C}$. The upper reagent mix contained a final concentration of 12.5 $\mathrm{mM}$ Tris- $\mathrm{HCl} \mathrm{pH} 8.3,62.5 \mathrm{mM} \mathrm{KCl}, 2.5$ units of AmpliTaq DNA Polymerase (Boehringer) and $10 \mu \mathrm{l}$ of cDNA. The total reaction volume was $50 \mu \mathrm{l}$ in each tube. The tubes were amplified in a Perkin Elmer 9600 thermal cycler for 30 cycles of $94^{\circ} \mathrm{C}$ for 1 minute, $55^{\circ} \mathrm{C}$ for 1 minute and $72{ }^{\circ} \mathrm{C}$ for 2 minutes.

\section{Southern Blot Analysis}

PCR products were electrophoresed in $1.5 \%$ agarose gels, visualised with ethidium bromide, and blotted onto nylon membranes (Boehringer). The filters were hybridised overnight at $65^{\circ} \mathrm{C}$ with a digoxigenin-labelled $\mathrm{C} \beta$ probe internal to all the PCR amplified sequences, then washed with $2 \times \mathrm{SSC} /$ $0.01 \%$ SDS followed by a final high-stringency wash with $0.5 \times \mathrm{SSC} / 0.01 \%$ SDS. A Fab fragment of antidigoxigenin antibody (Boehringer) was added followed by washes with $100 \mathrm{mM}$ Tris- $\mathrm{HCl}$ and $150 \mathrm{mM}$ $\mathrm{NaCl}$. Membranes were exposed to Kodak XAR-5 film at $-70{ }^{\circ} \mathrm{C}$ with an intensifying screen.

\section{Scanning Densitometry}

Following Southern blotting, scanning densitometry was used to determine the differences in intensity between V $\beta$ TCR transcripts of the same family members in HSK-susceptible and HSK-resistant mice. The relative intensities of the Southern blot band from each $V \beta$ amplification were measured in an ImageQuant densitometer (Molecular Dynamics, Sunnydale, CA) and were compared with the $C \beta$ values for the same sample. The results are expressed as the ratio of the densitometry value for the particular $\mathrm{V} \beta \mathrm{TCR}$ to the densitometry value for the $\mathrm{C} \beta$ TCR.

\section{RESULTS}

Stromal keratitis developed in only $7.4 \%$ of C.B-17 mice by day 11 and persisted through day 21 postinoculation, while it was present in $85.2 \%$ of C.AL20 mice by the same day post-infection.

More diverse $V \beta$ transcripts were seen at the later time points (days 11,14 and 21 ) in the inoculated eyes of C.AL-20 susceptible mice as compared with those of C.B-17 mice (Table II). Figs. 1 and 2 are examples of the different $V \beta$ transcripts found at 11 and 14 days post-inoculation. At day 11 in C.AL-20 mice, $\mathrm{V} \beta 2, \mathrm{~V} \beta 4, \mathrm{~V} \beta 5.1, \mathrm{~V} \beta 6, \mathrm{~V} \beta 9$ to $\mathrm{V} \beta 13, \mathrm{~V} \beta 15$, $\mathrm{V} \beta 16$ and $\mathrm{V} \beta 19$ were expressed (Fig. 1); in C.B-17 mice, those $\mathrm{V} \beta$ transcripts were not detected (Table II). At day $14, \mathrm{~V} \beta 1, \mathrm{~V} \beta 2, \mathrm{~V} \beta 4, \mathrm{~V} \beta 6, \mathrm{~V} \beta 7, \mathrm{~V} \beta 9$, $\mathrm{V} \beta 10, \mathrm{~V} \beta 13, \mathrm{~V} \beta 14$ and $\mathrm{V} \beta 16$ were expressed in C.AL-20 mice (Fig. 2) but were absent in C.B-17 mice (Table II). At day 21 post-inoculation, $V \beta 1$, $\mathrm{V} \beta 2, \mathrm{~V} \beta 4, \mathrm{~V} \beta 5.1, \mathrm{~V} \beta 6, \mathrm{~V} \beta 7, \mathrm{~V} \beta 8.1, \mathrm{~V} \beta 9, \mathrm{~V} \beta 11$, $\mathrm{V} \beta 12$ and $\mathrm{V} \beta 14$ were transcribed in C.AL-20 mice but not in C.B-17 mice (Table II).

The expression of $\mathrm{V} \beta 8$ family members was seen in both strains of mice at days 11,14 and 21 . However, the intensity of expression of $\mathrm{V} \beta 8.2$ and $V \beta 8.3$ was different between these strains of mice at day 11 , the time of onset of keratitis. The densitometry readings showed a significantly greater intensity in V $\beta 8.2$ and $V \beta 8.3$ message in C.AL-20 mice compared with C.B-17 mice (Fig. 3). V $\beta 8.1$ was expressed at day 11 only in C.B-17 mice (Fig. 1). At day 14 , both strains of mice showed mRNA gene expression of $V \beta 8.1, V \beta 8.2$ and $V \beta 8.3$ (Fig. 2), with different but not significantly different densitometer ratios (Fig. 4). The proportion of V $\beta 8.2$ message expressed by C.B-17 mice increased from day 11 to day 14 (Figs. 3, 4).

\section{DISCUSSION}

The critical role of the cellular immune response in 


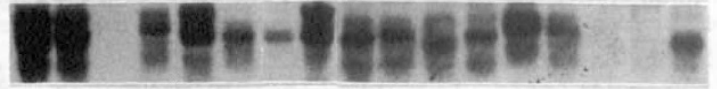

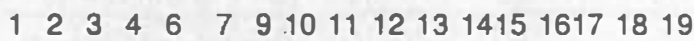

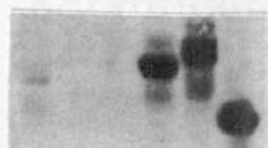

C.AL-20

$5.15 .28 .18 .28 .3 \mathrm{C} \beta$

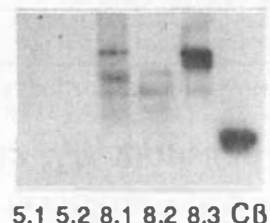

C.B-17

\section{$5.15 .28 .18 .28 .3 \mathrm{C} \beta$}

Fig. 1. TCR $V \beta$ gene expression in eyes of C.AL-20 and C.B17 mice, 11 days after corneal challenge with HSV. PCR products were detected by ethidium bromide staining followed by Southern blot. V $\beta 1$ to V $\beta 19$ from C.AL-20 mice are shown, as well as $V \beta 5$ and $V \beta 8$ family members for each mouse strain.

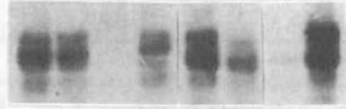

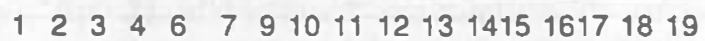

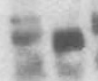

C.AL-20

$5.15 .28 .18 .28 .3 \mathrm{C} \beta$

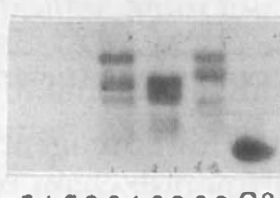

$5.15 .28 .18 .28 .3 \mathrm{C} \beta$

C. $B-17$

Fig. 2. TCR V $\beta$ gene expression in eyes of C.AL-20 and C.B17 mice, 14 days after corneal challenge with HSV. PCR products were detected by ethidium bromide staining followed by Southern blot. V $\beta 1$ to V $\beta 19$ from C.AL-20 mice are shown, as well as $V \beta 5$ and $V \beta 8$ family members for each mouse strain.

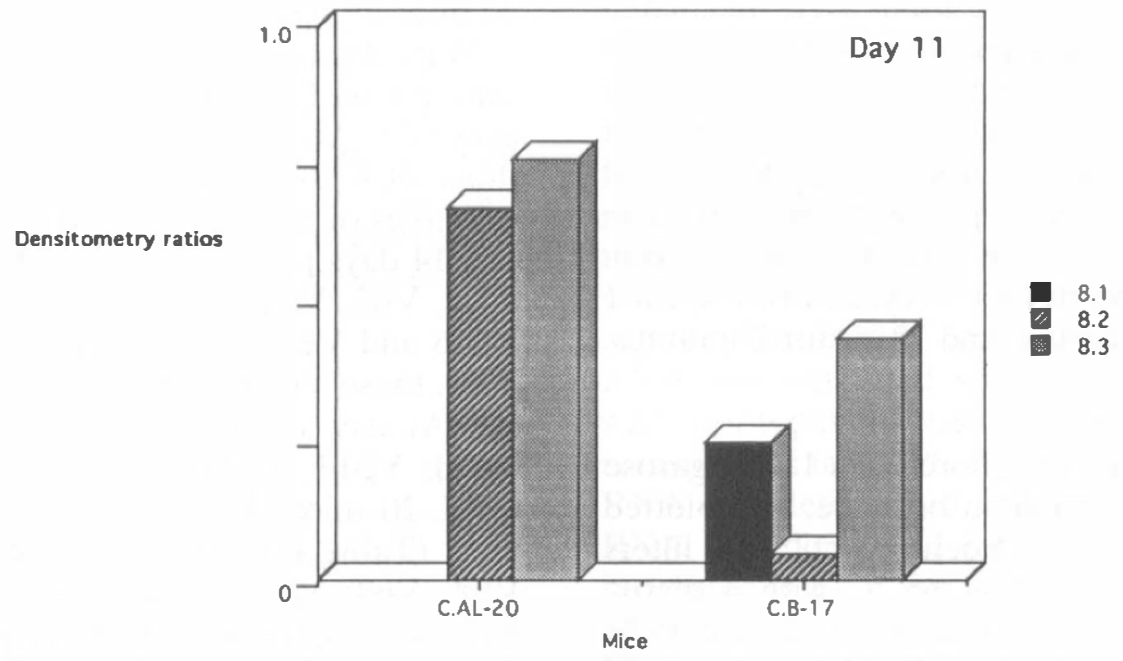

Fig. 3. Autoradiograms were quantified by image analysis as described in Methods. $V \beta / C \beta$ ratios of $V \beta 8$ family members, obtained from eyes at day 11 , are shown.

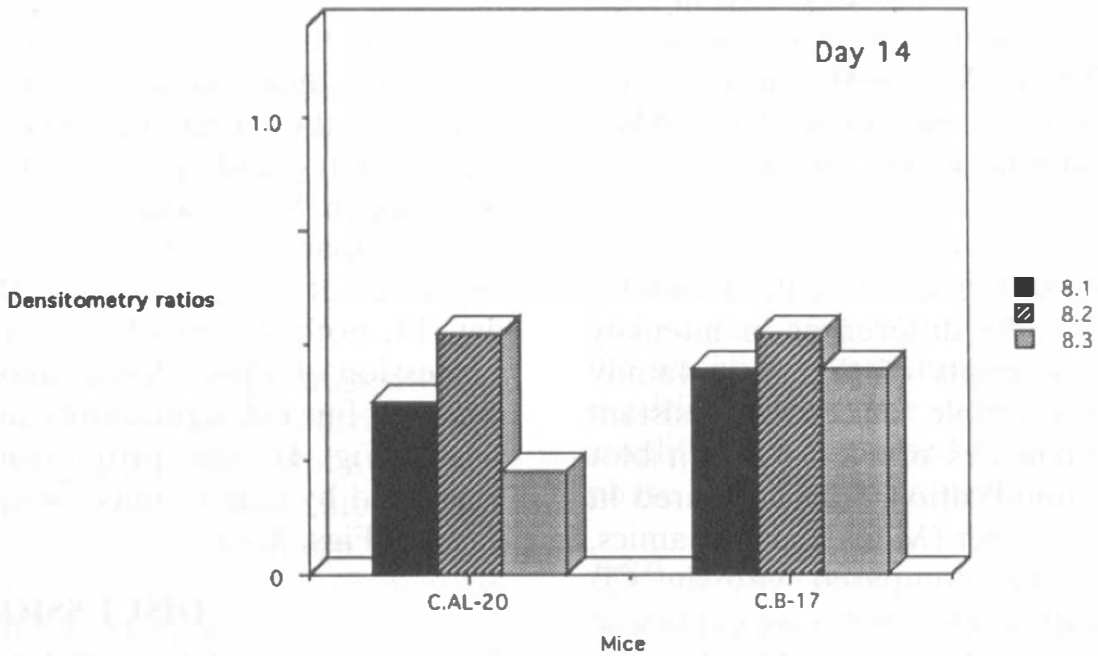

Fig. 4. Autoradinorams were auantified hv image analvsis as descrihed in Methods 
the pathogenesis of HSK has been shown in many studies. Nude mice inoculated in the cornea with herpes virus do not develop keratitis, while their normal littermates do. ${ }^{2}$ Russel et al. ${ }^{4}$ showed that the adoptive transfer of non-HSV-specific lymphoid cells into nude mice before HSV-1 corneal inoculation favoured the development of keratitis; HSK was even more severe when HSV-1 immune lymphoid cells were used in the transfer. Attempts to characterise the participation of different subsets of $\mathrm{T}$ cells show that the depletion of CD4 + cells by the in vivo administration of monoclonal antibodies protects mice from developing keratitis after HSV-1 inoculation, while CD8+ depletion does not, ${ }^{7}$ at least when $\mathrm{BALB} / \mathrm{c}$ mice are studied. When CD4+ T cells are adoptively transferred into thymectomised mice ${ }^{7}$ or nude mice $^{8}$ from immune donors, herpetic keratitis develops in the recipient mice following HSV inoculation of the cornea.

Effort has been directed towards defining the $\mathrm{T}$ cell repertoire in many human and experimental diseases, given the importance of possible immunointervention at that level. However, the interpretation of the data obtained has not been conclusive. Some authors provide evidence for a restricted $\mathrm{T}$ cell response in some diseases, ${ }^{14-21}$ while others find significant diversity in the range of TCR gene expression. ${ }^{22-25}$ In experimental autoimmune encephalomyelitis, restricted TCR V $\beta$ usage has been shown. Studies have consistently shown that specific monoclonal antibodies and vaccination with specific $T$ cells directed against V $\beta 8$ TCR protects animals from demyelinating disease (for review see Vandenbark et $a l^{26}{ }^{26}$. We previously reported that $\mathrm{T}$ cells bearing V $\beta 8.1,2 \mathrm{TCR}$, and to a lesser extent $\mathrm{V} \beta 3$ and $\mathrm{V} \beta 6$, were the main infiltrating cells into C.AL-20 corneas after HSV inoculation. ${ }^{9}$ It is clear from the results reported herein that these Igh-1 disparate, differentially HSK susceptible congenic mice are not responding to HSV corneal inoculation with different patterns of highly restricted preferential TCR usage, but have different TCR usage kinetics in response to HSV corneal inoculation. In general, more diverse $\mathrm{V} \beta$ transcripts were observed in eyes from HSKsusceptible mice, when compared with HSK-resistant mice, after HSV-1 corneal inoculation.V $\beta 5.1, \mathrm{~V} \beta 5.2$, $\mathrm{V} \beta 7, \mathrm{~V} \beta 8.2, \mathrm{~V} \beta 8.3, \mathrm{~V} \beta 9$ and $\mathrm{V} \beta 12$ were seen in eyes from C.AL-20 mice, but not at any time point in C.B17 mice.

The diverse $V \beta$ transcripts found in the eye did not represent a specific V $\beta$ TCR which could be responsible for the immunopathogenesis of HSK. This may suggest a possible systemic inhibitory factor generated in the resistant mice with subsequently fewer TCR V $\beta$ transcripts found in eyes, thus avoiding the exuberant inflammatory response to HSV and inhibiting development of HSK, while no such inhibitory factors are generated in susceptible mice, with the result that more $\mathrm{V} \beta$ transcripts were seen in eyes from HSK-susceptible mice.

Our data clearly show a diverse TCR V $\beta$ gene expression in this model, in accordance with the results of other authors who did not find a restricted TCR repertoire using different experimental models. ${ }^{22-25}$ At day 11 in eyes, we found significant differences in $V \beta 8$ family members between the Igh-1 disparate congenic strains of mice; increased intensity in the message in $\mathrm{V} \beta 8.2$ and $\mathrm{V} \beta 8.3$ was seen in C.AL-20 mice compared with C.B-17 mice. We find this especially interesting in the light of prior work which demonstrated a profound influence on the pathogenesis of HSK by a herpes glycoprotein-D peptide specific CD4+ V $\beta 8.2+$, IL-4 producing Th2 clone, ${ }^{10}$ and the findings that specific V $\beta 8 \mathrm{~T}$ cell subset depletion by using therapy with monoclonal antibodies prevents HSK development in HSKsusceptible mice. ${ }^{1}$ The differences that we found in $V \beta 8$ usage at the level of mRNA expression further support a role for the $\mathrm{V} \beta 8$ family members in the pathogenesis of experimental murine HSK. The possible role played by locally produced cytokines in the injured cornea of HSK-susceptible mice in the recruitment of specific $T$ cells with preferential $V \beta$ usage is currently under study in our laboratory.

This work was supported by NIH grant Ey06008.

Key words: Herpes simplex keratitis, Polymerase chain reaction, $\mathrm{T}$ cell receptor.

\section{REFERENCES}

1. Foster CS, Rodriguez Garcia A, Pedroza-Seres M, Berra A, Heiligenhaus A, Soukiasian S, et al. Murine herpes simplex virus keratitis is accentuated by CD4+, VB8.2+ Th2 T cells. Trans Am Ophthalmol Soc 1994; 91:325-50.

2. Metcalf JF, Hamilton DS, Reichert RW. Herpetic keratitis in athymic (nude) mice. Infect Immun 1979; 26:1164-74.

3. Oakes JE, Rector JT, Lausch RN. Lyt-1+ T cells participate in recovery from ocular herpes simplex virus type 1 infection. Invest Ophthalmol Vis Sci 1984;25:188-94.

4. Russel RG, Nasisse MP, Larsen HS, Rouse BT. Role of T-lymphocytes in the pathogenesis of herpetic stromal keratitis. Invest Ophthalmol Vis Sci 1984;25: 938-44.

5. Ksander BR, Hendricks RL. Cell-mediated immunity to HSV-1 corneal lesions. Invest Ophthalmol Vis Sci 1987;28:1986-93.

6. Foster CS, Opremcak EM, Rice BA, Wells PA, Chung $\mathrm{H}$, Thompson $\mathrm{P}$, et al. Clinical, pathologic, and immuno-pathologic characteristics of experimental murine herpes simplex virus stromal keratitis and uveitis controlled by gene products from the Igh-1 locus on chromosome 12. Trans Am Ophthalmol Soc 1987;85:293-311.

7. Doymaz M, Rouse B. Herpetic stromal keratitis: an immunopathologic disease mediated by $\mathrm{CD} 4+\mathrm{T}$ lymphocytes. Invest Ophthalmol Vis Sci 1992;33: 2165-73. 
8. Akoa YA, Dutt J, Rodriguez A, Jabbur N, Foster CS. The role of Igh-1 disparate congenic mouse $\mathrm{T}$ lymphocytes in the pathogenesis of herpetic stromal keratitis. Curr Eye Res 1993;12:1093-101.

9. Heiligenhaus A, Berra A, Foster CS. CD4+ V $\beta 8+T$ cells mediate herpes stromal keratitis. Curr Eye Res 1994;13:711-6.

10. Jayaraman S, Heiligenhaus A, Rodriguez A, Soukiasian S, Dorf ME, Foster CS. Exacerbation of murine herpes simplex virus-mediated stromal keratitis by Th2 type T cells. J Immunol 1993;151:5777-89.

11. Sandstrom IK, Foster CS, Wells PA, Knipe D, Caron L, Greene MI. Previous immunization of mice with herpes simplex virus type-1 strain MP protects against secondary corneal infection. Clin Immunol Immunopathol 1986;40:326-34.

12. Foster CS, Tsai Y, Monroe JG, Campbell R, Cestari M, Wetzig R, et al. Genetic studies on murine susceptibility to herpes simplex keratitis. Clin Immunol Immunopathol 1986;40:313-25.

13. Chomczynski P, Sacchi N. Single step method of RNA isolation by acid guanidinium thiocyanate-phenolchloroform extraction. Anal Biochem 1987;162:156-9.

14. Oksenberg JR, Stuart S, Begovich AB, Bell RB, Erlich HA, Steinman L, et al. Limited heterogeneity of rearranged $\mathrm{T}$-cell receptor $\mathrm{V} \alpha$ transcripts in brains of multiple sclerosis. Nature 1990;345:344-6.

15. Kotzin BL, Karuturi S, Chou YK, Lafferty J, Forrester $\mathrm{JM}$, Better M, et al. Preferential T-cell receptor $\beta$-chain variable gene use in myelin basic protein-reactive $T$ cell clones from patients with multiple sclerosis. Proc Natl Acad Sci USA 1991;88:9161-5.

16. Davies TF, Martin A, Concepcion ES, Graves P, Cohen L, Ben-Nun A. Evidence of limited variability of antigen receptors on intrathyroidal $\mathrm{T}$ cells in autoimmune thyroid disease. N Engl J Med 1991;325: 238-44.

17. Rodewald HR, Koszinowski UH, Eichmann K, Melchers I. Predominant utilization of $\mathrm{V} \beta 8+\mathrm{T}$ cell receptor genes in the $H-2 L^{d}$-restricted cytotoxic $T$ cell response against the immediate-early protein pp89 of the murine cytomegalovirus. J Immunol 1989;143: 4238-43.

18. Yanagi $\mathrm{Y}$, Maekawa $\mathrm{R}$, Cook $\mathrm{T}$, Kanagawa $\mathrm{O}$, Oldstone M. Restricted V-segment usage in $\mathrm{T}$ cell receptors from cytotoxic $\mathrm{T}$ lymphocytes specific for a major epitope of lymphocytic choriomeningitis virus. J Virol 1990;64:5919-26.

19. Aebischer T, Oehen S, Hengartner H. Preferential usage of $\mathrm{V} \alpha 4$ and $\mathrm{V} \beta 10 \mathrm{~T}$ cell receptor genes by lymphocytic choriomeningitis virus glycoprotein-specific $\mathrm{H}-2 \mathrm{D}^{\mathrm{b}}$-restricted cytotoxic $\mathrm{T}$ cells. Eur J Immunol 1990;20:523-31.

20. O'Neill HC. Preferential usage of the V $\beta 8$ gene family by CD4- CD8- T cell lines derived from spleen. Cell Immunol 1990;129:256-64.

21. Edouard P, Thivolet C, Bedossa P, Olivi M, Legrand $\mathrm{B}$, Bendelac A, et al. Evidence for a preferential $\mathrm{V} \beta$ usage by the $T$ cell which adoptively transfers diabetes in NOD mice. Eur J Immunol 1993;23:727-33.

22. Taylor AH, Haberman AM, Gerhard W, Caton A. Structure-function relationships among highly diverse $\mathrm{T}$ cells that recognize a determinant from influenza virus hemagglutinin. J Exp Med 1990;172:1643-51.

23. Giegerich G, Pette M, Meinl E, Epplen JT, Wekerle H, Hinkkanen A. Diversity of T cell receptor $\alpha$ and $\beta$ chain genes expressed by human $T$ cells specific for similar myelin basic protein peptide/major histocompatibility complexes. Eur J Immunol 1992;22:753-8.

24. Martin R, Utz U, Coligan JE, Richert JR, Flerlage M, Robinson E, et al. Diversity in fine specificity and $\mathrm{T}$ cell receptor usage of the human CD4+ cytotoxic $\mathrm{T}$ cell response specific for the immunodominant myelin basic protein peptide 87-106. J Immunol 1992;148: 1356-9.

25. Bell RB, Lindsey JW, Sobel RA, Hodgkinson S, Steinman L. Diverse $T$ cell receptor $V \beta$ gene usage in the central nervous system in experimental allergic encephalomyelitis. J Immunol 1993;150:4085-92.

26. Vandenbark AA, Hashim G, Offner H. TCR peptide therapy in autoimmune diseases. Int Rev Immunol 1993;9:251-76. 